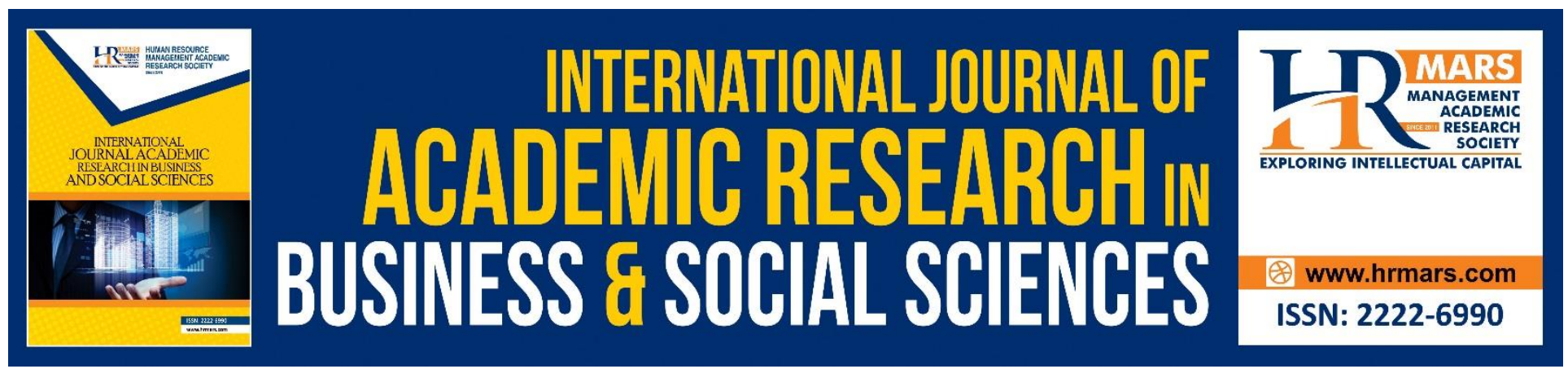

\title{
Analysis of the Development of Islamic Home Financing History in Malaysia
}

\section{Fathullah Asni \& Jasni Sulong}

To Link this Article: http://dx.doi.org/10.6007/IJARBSS/v9-i6/6039

DOI: 10.6007/IJARBSS/v9-i6/6039

Received: 18 April 2019, Revised: 20 May 2019, Accepted: 10 June 2019

Published Online: 29 June 2019

In-Text Citation: (Asni \& Sulong, 2019)

To Cite this Article: Asni, F., \& Sulong, J. (2019). Analysis of the Development of Islamic Home Financing History in Malaysia. International Journal of Academic Research in Business and Social Sciences, 9(6), 817-828.

Copyright: (C) 2019 The Author(s)

Published by Human Resource Management Academic Research Society (www.hrmars.com)

This article is published under the Creative Commons Attribution (CC BY 4.0) license. Anyone may reproduce, distribute, translate and create derivative works of this article (for both commercial and non-commercial purposes), subject to full attribution to the original publication and authors. The full terms of this license may be seen

at: http://creativecommons.org/licences/by/4.0/legalcode

Vol. 9, No. 6, 2019, Pg. $817-828$

http://hrmars.com/index.php/pages/detail/IJARBSS

JOURNAL HOMEPAGE

Full Terms \& Conditions of access and use can be found at http://hrmars.com/index.php/pages/detail/publication-ethics 


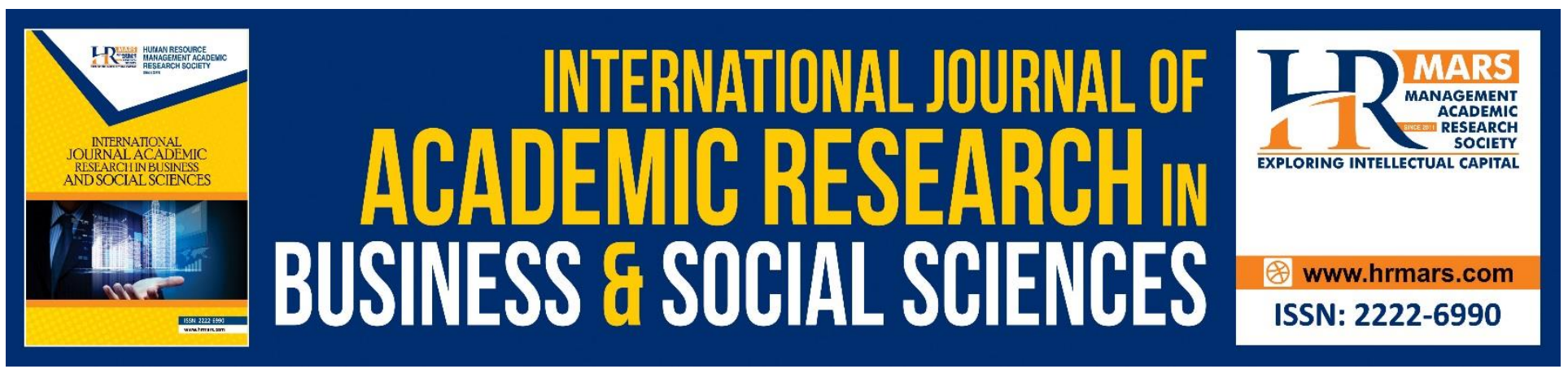

\title{
Analysis of the Development of Islamic Home Financing History in Malaysia
}

\author{
Fathullah Asni \& Jasni Sulong \\ School of Humanities, Universiti Sains Malaysia \\ Email: fathasni90@gmail.com,jasni@usm.my
}

\begin{abstract}
Home is a need since ancient times hitherto. Nowadays, to acquire a home requires high capital until one needs to get funding from other party either from individual or institutional. As a result, financial institutions were established and involved in assisting buyers. In the context of Malaysia, the facility led to an establishment of a housing financing contract between bank and buyers since before the Independence Day. For Muslims, the contract was formulated to be Shariah compliance within conventional framework. Hence, this study aims to examine the development of Islamic housing financing contracts since before the independence hitherto. This study using a qualitative method in which the researchers have applied a library research method to obtain secondary data through books, journals and official websites. The study found that housing financing contracts have undergone a phase of change from a simple to a complex contract form by combining multiple contracts. The study also found that the financing contracts have undergone a transformation phase of Islamic-based products that are based on sale and purchase to Islamic based partnership products which were more in line with Shariah requirements. Housing financing products are also change to a better direction as Islamic banks as well as Shariah advisors always responded to any critics to improve their products.
\end{abstract}

Keywords: Islamic Housing Financing, Bank Islam, History, Malaysia, Shariah compliance

\section{Introduction}

Home is a basic necessity for every human being since ancient times until now (Azli et al., 2011). But to get a home is challenging at the present time as the value is increasing and hence require high expenses. Its high value cannot be saved for a short period of time, and this requires other financial resources. Currently, people get such resources through various means either through financing, borrowing, saving money gradually or even renting (Besar et al., 2012).

However, for Muslims, they are forbidden to involve in as the Quran has commanded Muslims to do sales and avoid usury (Q2:275). While at the same time, it is hard for individuals to lend a large amounts of money without taking any interest or benefit. Therefore, the Islam prohibited loan and instruct Muslims to involve in other muamalat methods in getting funds for buying home. It is found 
that since before Malaysia's independence, Muslims have gotten an enormous fund for financing. The product of Islamic housing financing was also boomed when it was initially offered by the Islamic Bank since the launch of the Islamic Banking Act 1983 which came into force on 7 April 1983 (Ismail et al., 2015). From the perspective of the study gap, there has been no study to discuss the details of the historical development of Islamic housing financing in Malaysia. Hence, this study is to investigate the historical development of Islamic housing financing in Malaysia since before the establishment of Islamic Bank in Malaysia as an alternative to conventional-based banks.

\section{Historical Development of Islamic Housing Financing in Malaysia}

Before Independence 1957

Based on history, Islamic financial transactions have been practiced in Malaya as early as 16th century through the influence of Malacca's law. It was witnessed that most of the states in Malaya at that time have similar provisions with Legal Code of Malacca on muamalat matters (Cortesa, 1944; Fang, 1976; Winsted, 1958; Shellebear, 1977). In the Code, muamalat affairs are listed from clause 29 to clause 34.2 among which the section 30 that have underlined the prohibition of riba (usury) in any transaction (Nasohah, 2004). However, the listed dealings were handled in informal manners such as between sellers and buyers.

Among traditional practice was "conditional sale" that were applied among Muslim communities, especially by farmers in Kedah, Perlis, North Perak and Kelantan pre-colonial times. This contract was practiced in replacing money lending scheme that became the core economic business of the Chettiars in Malaya (Maxwell, 1974; Gullick 1987; The National Land Code, Section 4 (2)). Instead of colonial system that based on usury, the chettiars also play a significant role in lending and loaning services that based on interest charge.

According to Buang (1993), the conditional sale is a resemblance of Islamic principle which was known by al-bay' al-wafa, that is the sale with the option to repurchase. Al-Bay' al-Wafa' contains two words that are al-bay' means sale, and al-wafa' means repayment or settlement of the debt. In application, Islamic jurists have defined it as a sale and purchase by two parties that involve a condition that the goods sold can be repurchased by the seller upon a specified period of time (al-Zarqa', 1968). The purpose of the transaction is to obtain a sum of capital that are free of usury and the buyer have rights to benefit of land or other asset, during the period of agreement (Hasan, 2005). If the seller is failing to repurchase the asset during the time agreed, the property is belonging to the buyer for permanent (Buang, 1988).

Originally, the contract was found being practiced by people in Central Asia (Bukhara and Balkh) in the middle of the 5th century of Hijra to avoid loaning activities and usury. The practice continued to expand into the Middle East, then brought to the Malay Archipelago by Muslim traders which is in line with the inclusion of Islam (al-Sabuni, 1980). The practice is not just to obtain a capital but also prevent usury elements. Then it develops to be a local culture among Malay Muslim community who aware in avoiding usury. Usually, this contract is practiced in the sale of land or other fixed properties with provision to repurchase within a specified period. During that period, the buyer can benefit and occupy the land completely (Buang, 1988).

Such practice is as an alternative to avoid involvement in usury and the fact was mentioned by colonial judges as well as by Malay judges. In the case of Tungku Zahara v Che Yusof (1951), Briggs J. 
decided that the purpose of the conditional sale transaction was to obtain credit (debt) and to give the mortgagor (land buyer) a corresponding indemnity without engaging in the practice of riba (usury). In the case of Ibrahim (1968), Azmi as the Chief Judge of Malaya had made the same statement that the customary practice of the Kedah farmers was basically a conditional sale, in which the seller had the right to repurchase his property and to enable the buyer (borrower of money) to benefit from legal transactions according to Islamic law (Yasin, 1996). These statements have proven and reinforced that bay' al-wafa' was an alternative arrangement by the Malay community at that time to avoid riba transactions.

However, the form of dealing became culture of local community and they used to take the arrangement in getting instant capital. The focus group of this mode of dealing was revolving around folk farmers who living in kampong and rural community (Shamsuddin, 1988). The richer among them would be the focal point of the villagers to sell their asset. As sum, the type of dealing is significant to be developed as a basis of shariah compliance products, especially in initiating a non-usury funding. From other perspectives, it is a kind of mortgage where value and benefit of the asset will become as financial considerations. In addition to the land for agricultural activities and income sources, the land was also the place to live. The Scheme was continued until after the independence even though after the establishment of Bank Islam in Malaysia on 7 April 1983 (Maxwell, 1974; hooker, 1974; Gullick, 1987). Indirectly, the practice became principle of home financing at that time under the contract of conditional sale (al-bay' al-wafa'). However, majority of Islamic jurists have denied the validity of albay' al-wafa' and consider it as an irregularity sale because there is an element of hilah and involve with obligatory terms in the sale and purchase (Hawwa, 2007). The similar resolution also found by the Majma' Fiqh al-Islami in 1992 (Majma' Fiqh al-Islami).

\section{After Independence 1957}

After Malaysia gained independence, the legacy of colonial influence continuing especially in financing matters which practice interest or usury in lending contract. The practice is contrary to the Islamic law which resulted difficulty for Muslims to get capital financing from financial institutions. Only in 1969 after the establishment of Lembaga Urusan Tabung Haji (LUTH), Muslims in Malaysia were provided with Shariah compliance institution (Aziz, 1959; LUTH, 1980). However, the institution is only provide saving facility to enable Muslims to save money for pilgrimage (LUTH, 1991). The need for Islamic banks to be established in Malaysia become obvious when looking at the success factors of the establishment of Islamic banks in some Muslim countries such as Qatar, UAE, Egypt, Pakistan and Iran.

Therefore, on 1 March 1983, the first Islamic bank was established in Malaysia known by Bank Islam Malaysia Berhad (BIMB). It was incorporated as a company under the Companies Act 1965. The objective of the establishment is to offer Islamic banking scheme that is fully Shariah compliant. Among of the Islamic products that were introduced was the Islamic housing financing product. In early establishment of Islamic bank in Malaysia, it took the model of overseas Islamic bank namely Faisal Islamic Bank in Sudan and Faisal Islamic Bank in Egypt (Hassan, 2005). The establishment of $B I M B$ as well as its instruments for the first decade was contributing as the first phase of implementation of the Islamic Banking System (SPI) in Malaysia (Ismail, 1983). 
The second phase start after 1990s, that brought SPI system from the periphery of the banking to the mainstream structure (Yakcob, 1996). At this stage, several phases were initiated which allowing conventional financial institutions to offer Islamic banking services. All commercial banks, merchant banks and finance companies were eligible to participate in SPI. The first phase was launched in March 1993 involving the three largest commercial banks in Malaysia namely Malayan Banking Berhad (MBB), Bank Bumiputera Malaysia Berhad (BBMB) and United Malayan Banking Corporation Berhad (UMBCB) (Borhan, 2001). The three banking institutions had granted permission to offer SPI, beside their current role in conventional banking. Among facilities that were offered specifically depository accounts, asset ownership financings such as residential and trade financing. All products were based on Shariah principles that are wadi'ah, mudarabah, bay' bithaman' ajil, ijarah, kafalah and wakalah (Ghani, 1999). The SPI service had received encouraging response from the public. Through 281 branches of the three banks, within two months of operation, they had attracted 4,146 depositors and raised a total of 30 million deposit money (Guan, 2002).

The second phase of the implementation of SPI was launched on 21 August 1993 which involves 10 other financial and banking institutions. Among them were Perwira Habib Bank Berhad, Arab Malaysian Finance Berhad and Maybank Finance Berhad. At that time, the entire branch of those financial institutions were offering SPI that amounted to 440 units, excluding 44 of the BIMB branches. Until end of December 1995, the number of financial institutions that participated in SPI was 42, with a total of branches offering SPI facilities was 1472, involving 66 BIMB branches and 1406 of other banks' branches (Borhan, 1999).

On $1^{\text {st }}$ October 1999, Bank Muamalat Malaysia Berhad (BMMB) was established as the second Islamic bank in Malaysia. BMMB is developed by the government's efforts to strengthen the Islamic banking sector to meet the growing demand for the public on Islamic banking services (Borhan, 2011). On May 5, 1993, the Shariah Banking System was introduced by Bank Kerjasama Rakyat Malaysia (Bank Rakyat) which started through its four branches. By the end of 1995, 40 Bank Rakyat branches were fully operating as Islamic banking institution (Bank Rakyat, 1994).

From the perspective of home financing, as BIMB took Faisal Islamic Bank's banking model at the beginning of its establishment, it come together with their financing products such as bay' 'inah and BBA to be practiced in Malaysia. The two products also recognized by other Islamic banks during the early phase of the establishment of Islamic banks in Malaysia (Shahwan, et al., 2013). In sum, these products also were offered by other banks that operate on dual-window scheme. According to Hanafi (2012), bay' 'inah and BBA products had dominated for 35 years since the commencement of Islamic banking in Malaysia. Meanwhile, Islamic banking products at international level more popular with murabahah-based products which using direct selling on profit purposes. However, in Malaysia the practice of Islamic financing within conventional system have led bankers tend to count profit at par with conventional product. Hence, to avoid incurring more liability on home financing and get profit as similar as the other products, bay' inah was preferred. In addition, the need for buyer to pay at least $10 \%$ to developers has raised constraint to apply murabahah scheme. Generally, Islamic housing financing products in Malaysia have three phases, namely the stage of emerging debt-based products such as BBA and tawarruq. The second stage was hire-purchase products such as al-ijarah muntahiyyah bi al-tamlik and al-ijarah mausufah fi al-dhimmah while the third stage was producing equity-based products such as musyarakah mutanaqisah (Hanafi, 2012). 
In detail, BBA or bay' bithaman ajil is a combination of three contracts, i.e. al-bay' (sale), thaman (price) and ajil (delay of time). In terminology, BBA is a sale and purchase agreement between the owner of goods and the buyer where the owner of goods handed the items to the buyer immediately, and the buyer delayed the price of payment until a certain period that was agreed between them (Aziz, 2013). Under BBA contract, element of bay' 'inah embedded in the contract (Shahwan, et al., 2013). Meanwhile in real process, financing bank does not has a connection with developer to purchase a home, as it is between buyer and bank only. When buyer paid $10 \%$ payment to developer, the former has to get financing from bank and therefore involve bay' 'inah contract with bank (shuib, et al., 2013). Until year 2000, BBA products dominated over other products in Malaysia as they were popular and widely used (Hassan, 2005).

Based on the practice of bay' 'inah through BBA in Malaysia, it has been widely criticized among Middle Eastern scholars as the contract is overwhelmed with issues of trickery and usury which were prohibited by Shari'ah (Zain, et al., 2017). Hence, some of the Islamic banks such as BIMB, Bank Rakyat and Arab (M) Bank were shifted to tawarruq-based product which was approved by the Shariah Advisory Council of the Central Bank in its 51st meeting on 28 July 2005. The acceptance of Islamic Financial Institutions (IFI) towards tawarruq product was encouraging and favored among other products (Ab Rahman, et al., 2010). The modus operandi of tawarruq is slightly difference compared to bay' inah as the former is involving two levels of transactions. At the first level, transaction involves a credit purchase between buyer and seller of an asset, and at the second level, the buyer will then sell the asset in cash to the third buyer. Majma 'al-Fiqh al-Islami defines bay' al-tawarruq as to buy something in possession of a seller on a debt, then a buyer sells it to a third party for obtaining cash (Ab Rahman, et al., 2010).

This contract is called bay' al-tawarruq because when a buyer buys an asset on credit, the buyer does not intend to use or utilize it, but only wants to sell it again for cash. Tawarruq contract is also known as commodity contract of murabahah and is widely used in depository product, financing, asset management and liabilities, and risk management. The tawarruq contract contains several agreements namely credit purchase agreements and resale asset for cash. Based on current practice on tawarruq scheme such as in the Muamalat bank, the financing structure involves several other contracts namely bay' murabahah, wa'd mulzim, wakalah and bay' wadi'ah (Mahyudin, 2015).

In the third phase, banks began offering rental and purchase-based product that was also included in debt-based financing categories to diversify financing products. It was known as al-ijarah muntahiyyah bi al-tamlik and al-ijarah al-mausufah fi al-dhimmah. Generally, ijarah muntahiyyah bi al-tamlik is referred to ijarah contract that was a beneficial ownership which acquired through exchange of payments whether in the form of equivalent assets, debt or benefits (Suhaimi, 2010). Practically, ijarah agreement only involves benefit taking of an asset from owner (bank) to tenant (customer), without involving a transfer of property rights. The owner still owns the ownership rights those assets (Bank Negara Malaysia, 2009).

ljarah contract in its original form is not a means of financing, as it is a lease contract. However, it has been invented as a financing instrument by solemnizing the contract of leasing with full ownership transfer. Hence, instead of taking benefit on the asset, the tenant also owns an ownership at the end of the contract. This innovation creates a product named ijarah muntahiyyah bi al-tamlik which comprises three contracts, i.e. rent, sale and wa'd mulzim (Hakimah, et al., 2016). The lease deal will 
take effect at the initial stage of the contract whereby the tenant will rent and pay the fee to an owner (bank) according to agreeable rate and identified timeframe. After rental period is accomplished or all payments have been made, the rental asset become a tenant's purchased property (Kuwait Finance House, 2018). According to Ayub (2007), ijarah muntahiyyah bi al-tamlik contract is a hybrid contract with good prospects as there is no controversial issues found in the arrangement of contracts.

In a meantime, contract ijarah mausufah fi al-dhimmah is almost similar to contract ijarah muntahiyyah bi al-tamlik, both of them are using ijarah contract. ljarah al-dhimmah can be defined as a sale of future benefit to obtain cash or a salam contract to obtain benefits whether the benefit arise from the assets or services. It was acknowledged as ijarah al-dhimmah because benefit of the asset was placed on the tenant's liability which not attribute to the asset itself. It can also be termed as ijarah whose benefits are guaranteed as the lessor assured to provide such benefits in any event. This contract is also considered a salam where the subject is a benefit. ljarah al-mausufah fi aldhimmah contract has involved four sub-contracts namely istisna', ijarah, bay' and wa'd mulzim. The modus operandi of financing involve bank as the homeowner financing that funding a developer to build house. This process indirectly uses an istisna' contract. Subsequently, the bank leases the house to customer based on the amount and rental period agreed upon using the lease contract. Then at the end of the rental period, the bank will sell the house to the customer either at the rent price or nominal value, using the sale and wa'ad contracts.

Although the al-ijarah muntahiyyah bi al-tamlik product was approved by the Shariah Advisory Council (SAC) of Malaysian Central Bank on 1997 and 2003, followed by ijarah mausufah fi dhimmah in 2010 as a housing financing product, but until to this day, both products are not widely applied in Islamic home financing products (Bank Negara Malaysia, 2010).

In the fourth phase, banks began to offer equity-based products such as musharakah mutanaqisah (MM) or diminishing partnership. This product was developed by muamalat scholars and subsequently was implemented by Islamic banks to highlight the concept of profit and loss sharing between the bank and the client, which is very different from conventional concepts that only prioritize profit in whatever risk and condition. This product was approved by the Shariah Advisory Council (SAC) of Malaysian Central Bank at the 56th meeting held on 6 Feb 2006 (Osmani, et al., 2010). MM product has started offering by Kuwait Finance House (Malaysia) Berhad (KFH) (2019) on February 17, 2006, Citibank (2019) on March 6, 2007, Maybank Islamic (2019) on September 12, 2007, RHBIB (2019) on November 22, 2007, Affin Bank (2019) on May 6, 2011, and followed by HSBC, SCS and PIB (Osmani, et al., 2010). Internationally, musharakah mutanaqisah product has been approved at the international seminar on Islamic banks in Dubai in 1979 where at that time, only few of the Islamic banks using the product (Smolo, et al., 2011). Musharakah mutanaqisah contract is a concept of a downward partnership that ends the contract with ownership. Musharakah from the Arabic term is derived from the basic word that is sharika or sharikah which means to associate or share. Mutanaqisah means it is diminishing. According to the term, musharakah mutanaqisah is a form of partnership in which one of the partners' promises to buy the equity share of the other partner gradually until the title to the equity is completely transferred to him (Samsudin, 2015). Musharakah mutanaqisah contract involves several other contracts that merge in an agreement which consist of musyarakah, ijarah and bay'. In the implementation of this contract at RHBIB, there 
INTERNATIONAL JOURNAL OF ACADEMIC RESEARCH IN BUSINESS AND SOCIAL SCIENCES Vol. 9, No. 6, June, 2019, E-ISSN: 2222-6990 (C) 2019 HRMARS

was one more contract be added namely wa'd mulzim (Shuib, et al. 2011). According to Shuib (2011), the combination of those contracts is in line with the Shariah after fulfilling requirements of every contract.

Table 1: Islamic Housing Financing Products (Bank Negara Malaysia, 2019);

\begin{tabular}{|c|c|c|}
\hline & Bank Names & Housing Financing Products \\
\hline \multirow[t]{2}{*}{1} & \multirow{2}{*}{$\begin{array}{c}\text { Kuwait Finance } \\
\text { House }\end{array}$} & Ijārah Muntahiah Bi Tamlikk \\
\hline & & Ijārah Maușüfah Fi Dhimmah \\
\hline 2 & Bank Islam & Tawarruq \\
\hline 3 & Maybank & Tawarruq \\
\hline 4 & Am Bank & Tawarruq \\
\hline 5 & Public Bank & $\begin{array}{c}\text { Bai Bithaman 'Ājil } \\
\text { Mushārakah Mutanāqișah } \\
\text { Ijārah Mawșūfah fĩal-Dhimmah }\end{array}$ \\
\hline 6 & Alliance bank & Bai Bithaman 'Ājil \\
\hline 7 & Bank Rakyat & Tawarruq \\
\hline 8 & Affin Bank & $\begin{array}{c}\text { Mushārakah Mutanāqișah } \\
\text { Tawarruq }\end{array}$ \\
\hline 9 & BSN & Tawarruq \\
\hline 10 & $\begin{array}{l}\text { Hong Leong } \\
\text { Islamic Bank }\end{array}$ & Tawarruq \\
\hline 11 & RHB & Mushārakah Mutanāqișah \\
\hline 12 & Al-Rajhi & Tawarruq \\
\hline 13 & Bank Muamalat & Tawarruq \\
\hline 14 & CIMB Bank & Tawarruq \\
\hline 15 & OCBC Bank & Ijārah Muntahiah bi Al-Tamlik \\
\hline 16 & MBSB Bank & Tawarruq \\
\hline
\end{tabular}

Based on table 1, there are now 16 banks that offer Islamic housing financing services based on different products, i.e. ijarah muntahiyyah bi tamlik, ijarah mausufah fi dhimmah, tawarruq, bay' bithaman 'ajil and musharakah mutanaqisah. The majority of the financing products offered are based on tawarruq where 11 banks offer it. It was followed by musharakah mutanaqisah based products where three banks offer it. Then, followed by ijarah muntahiyyah bi tamlik, ijarah mausufah fi dhimmah and bay' bithaman 'ajil which each of them are offered by two banks.

\section{Conclusion}

Based on an above discussion, the source and types of Islamic funding before independence were offered and managed by individuals. However, after independence, the development of Islamic 
financing activities gradually changed from individual to institution, especially after the establishment of the Islamic bank in Malaysia. The progress was continuing to apply when the Central Bank had launched an Islamic banking scheme where conventional banks also were allowed to offer them. The consequence has resulted all registered banks which involved in offering Islamic financing products can offer the facilities. Hence, this has contributed to the greater supply of Islamic housing financing to accommodate Muslims in Malaysia.

Islamic housing financings have undergone a transformation phase from a simple product to a complex form. This can be seen through bay' al-wafa' before independence, then expanded to the BBA product that based on a bay' al-'inah after independence. Then the product continues to expand in the form of tawarruq munazzam contract. Subsequently, it shifted to rental-based products, i.e. ijarah muntahiyyah bi al-tamlik and ijarah mawsufah fi al-dhimmah. Then, the changes remain to a partnership based under the brand of musharakah mutanaqisah. Overall, the transition took place on several factors, among which as a respond to criticisms from muamalat scholars either locally or internationally. The rest are wanting to diversify Islamic housing financing products, utilizing the Islamic muamalat contracts in classical fiqh as well as absorbing the elements of sharing in the face of economic risks. As sum, the development of Islamic housing financing products is improving and offered in several products which compliance with Shariah.

\section{Corresponding Author}

Fathullah Asni

School of Humanities, Universiti Sains Malaysia, 11800 Pulau Pinang, Malaysia

Email: fathasni90@gmail.com

\section{Acknowledgement}

The research is funded by the Fundamental Research Grant Scheme (FRGS) by the Higher Education Ministry of Malaysia, Phase 1/2017, No. 203/PHUMANITI/6711589.

\section{References}

Ab Rahman, A., Mohammad, S., \& Salleh, I. M. (2010). Bay' al-Tawarruq Dan Aplikasinya Dalam Pembiayaan Peribadi Di Bank Islam Malaysia Berhad. Jurnal Syariah, 18(2).

Affin Bank. (2019). Musharakah Mutanaqisah. See: http://affinbank.com.my/news/06052011bi.htm (accessed on 5/4/2019).

Al-Sabuni, A. R. (1980). al-Madkhal li Dirasah al-Tasyri' al-Islami. Dimasyq: Matba'ah al-Riyad. Al-Zarqa', A. (1968). Sharh al-Qanun al-Suri, al-'Uqud al-Musawamah. Dimasyq: Dar al-Kitab. Ayub, M. (2007). Understanding Islamic Finance (Vol. 462): John Wiley \& Sons.

Aziz, A. (2013). Perlaksanaan prinsip al-Bay'Bithaman Ajil dalam pembiayaan perumahan: analisis di Bank Kerjasama Rakyat Malaysia dan Bank Muamalat Malaysia Berhad (Master dissertation, University of Malaya).

Aziz, U. A. (1959). Pilgrims Economy Improvement Plan. Kuala Lumpur,

Azli, R. M., Othman, R., Sahri, M., Aris, N. A., Arshad, R., \& Yaakob, A. R. (2011). Implementation of Maqasid Shari'ah In Islamic house financing: A study of the rights and responsibilities of 
INTERNATIONAL JOURNAL OF ACADEMIC RESEARCH IN BUSINESS AND SOCIAL SCIENCES

Vol. 9, No. 6, June, 2019, E-ISSN: 2222-6990 @ 2019 HRMARS

contracting parties in Bai'Bithaman Ajil and musharakah mutanaqisah. Journal of Applied Business Research, 27(5), 85-96.

Bank Negara Malaysia. (2009). Concept Paper on Shariah Parameters References 2: Ijarah Contract.

Bank Negara Malaysia. (2010). Syariah Resolution in Islamic Finance (Second Edition). See: (http://www.bnm.gov.my/microsite/fs/sac/shariah_resolutions_2nd_edition.pdf) (accessed on 5/4/2019).

Bank Negara Malaysia. (2019). Islamic Housing Financing Products. See: http://www.bnm.gov.my/ (accessed on 5/4/2019).

Bank Rakyat. (1994). Melalui Liku Sejarah Bank Rakyat. Ma/a/a/i Rakyat. Bil. 13.

Besar, J. A., Fauzi, R., \& Ghazali, A. S. (2012). Penilaian awal impak perlaksanaan Dasar Perumahan Negara terhadap sektor perumahan di Kuala Lumpur. Geografia: Malaysian Journal of Society and Space, 8(6), 90-108.

Borhan, J. T. (1999). Bank Islam Malaysia Berhad: Some Issues, Problems and Its Prospects in the Future. Jurnal Syariah 7(2): $114-117$.

Borhan, J. T. (2001). Sistem Perbankan Islam di Malaysia: Sejarah Perkembangan, Prinsip dan Amalannya. Jurnal Usuluddin, 14, 137-164.

Buang, S. (1988). "Ke Arah Pengislaman Kanun Tanah Negara" in Faculty of Law University Malaya. Makalah Undang-undang Menghormati Ahmad Ibrahim. Kuala Lumpur: Dewan Bahasa dan Pustaka.

Buang, S. (1993). Undang-undang tanah di Malaysia. Kuala Lumpur: Dewan Bahasa dan Pustaka

Citibank. (2019). Musharakah Mutanaqisah. See: http://www.citi.com/citigroup/press/2007/070306c.htm (accessed on 5/4/2019).

Cortesa, A. (1944). The Suma Oriental of Tom Pires. London: E.G.De Eredia

Fang, L. Y. (1976). Undang-Undang Melaka. The Hague: Martinus Nijhoff

Ghani, A. M. (1999). Sistem kewangan Islam dan pelaksanaannya di Malaysia. Kuala Lumpur : Jabatan kemajuan Islam Malaysia.

Guan, C. K. (2002). Sistem Kewangan Malaysia : Struktur, Perkembangan dan Perubahan. Kuala Lumpur: Pearson Malaysia SDN. BHD.

Gullick, J. M. (1987). Malay society in the late nineteenth century: The beginnings of change. Oxford University Press, USA

Gullick, J. M. (1987). Malay society in the late nineteenth century: The beginnings of change. USA: Oxford University Press.

Hakimah, M. Z., Salamon, H., Abdullah, N. I. (2016). Pembiayaan Aset Berasaskan ljarah Di Malaysia Dan Isu-Isu Berkaitan. Journal of Global Business and Social Entrepreneurship (GBSE), 2(1): 121129

Hanafi, H. (2012). Critical Perspectives on Musharakah Mutanaqisah Home Financing in Malaysia: Exploring Legal, Regulative and Financial Challenges (Doctoral dissertation, Durham University).

Hassan, A. A. H. (2005). Teori dan aplikasi kontemporari sistem ekonomi Islam di Malaysia. Kuala Lumpur: Utusan Publications.

Hawwa, A. S. (2007). Suwar al-Tahayul 'ala al-Riba. Beirut: Dar Ibn Hazm

Hooker, M. B. (Ed.). (1974). Readings in Malay adat laws. NUS Press. 
INTERNATIONAL JOURNAL OF ACADEMIC RESEARCH IN BUSINESS AND SOCIAL SCIENCES

Vol. 9, No. 6, June, 2019, E-ISSN: 2222-6990 @ 2019 HRMARS

Ismail, A. H. (1983). Bank Islam Malaysia Berhad: Establishment and Operation. Prosiding. International Conference on Islam and Technology, UTM, Kuala Lumpur, Dec. 1983.

Ismail, M. Z., Rosland, A., Mohamad, M. T., Ahmad, N. H., (2015). Perbankan Islam Di Malaysia: Tinjauan Strategi Pengukuhannya. Labuan e-Journal of Muamalat and Society, 9, 48-56.

KFH . (2019). Musharakah Mutanaqisah. See: http://www.kfhonline.com.my/kfhmb/ep/kfhContentView.do?contentTypeld=3000\&channell $\mathrm{d}=-$

9242\&displayPage=\%2Fep\%2Fcontent\%2Fkfh_editorial_content.jsp\&programld=10624\&page Typeld=8 622\&contentld=8092; Laporan Tahunan KFH 2006, 41 (accessed on 5/4/2019).

Kuwait Finance House. (2018). PRODUCT DISCLOSURE SHEET. http://www.kfh.com.my. (Seen on $6 / 1 / 2018)$.

LUTH. (1980). Lembaga Urusan dan Tabung Haji Sebagai Satu Institusi Pelaburan Islam. Kuala Lumpur.

LUTH. (1991). Tabung Haji As An Islamic Financial Institution: The Operation and Mobization of Investment Resources In An Islamic Way. Kuala Lumpur.

Mahyudin, M. I. (2015). Aplikasi tawarruq dalam sistem perbankan Islam: kajian di Bank Muamalat Malaysia Berhad (Master dissertation, Jabatan Syariah dan Ekonomi, Akademi Pengajian Islam, Universiti Malaya).

Majma' Fiqh al-Islami, 7th Conference in Jeddah, Sa'udiyyah, 9 - 14/5/1992.

Maxwell, W. E. (1974). THE LAW AND CUSTOMS OE THE MALAYS WITH REFERENCE TO THE TENURE OF LAND. Readings in Malay Adat Laws.

Maybank Islamic. (2019). Musharakah Mutanaqisah. See:

http://www.maybank2u.com.my/corporate/press_release/2007/120907.shtml (accessed on 5/4/2019).

Nasohah, Z. (2004). Pentadbiran undang-undang Islam di Malaysia: sebelum dan menjelang merdeka. Kuala Lumpur: Utusan Publications.

Osmani, N. M., \& Abdullah, M. F. (2010). Musharakah mutanaqisah home financing: A review of literatures and practices of Islamic banks in Malaysia. International Review of Business Research Papers, 6(2), 272-282.

RHBIB. (2019). Musharakah Mutanaqisah. See: http://www.rhbislamicbank.com.my/index.asp?fuseaction=financing.main. (accessed on 5/4/2019).

Samsudin, Z. (2015). Aplikasi Musyarakah Mutanaqisah Dalam Pembiayaan Mikro Kewangan Islam. Jurnal Syariah, 23(2), 217-234.

Shahwan, S., Mohammad, M. O., \& Rahman, Z. A. (2013). Home financing pricing issues in the Bay'Bithaman Ajil (BBA) and Musharakah Mutanaqisah (MMP). Global Journal AlThaqafah, 3(2), 23-36.

Shamsuddin, A. K. (1988). Banking and Public Finance in Islam. Kuala Lumpur: Dewan Pustaka Fajar Shellebear, W. G. (1977). Sejarah Melayu. Kuala Lumpur: Penerbit Fajar Bakti Sdn. Bhd.

Shuib, M. S., Mohamad, M. T., \& Sulaiman, A. A. (2013). Kemungkiran pemaju dalam produk pembiayaan perumahan secara Islam: analisis pendekatan penyelesaian. Jurnal Pengurusan, 38, 141-149. 
Shuib, M. S., Sulaiman, A. A., \& Mohamad, M. T. (2011). Pembiayaan perumahan secara Islam di Malaysia: Analisis kelebihan produk berasaskan musharakah mutanaqisah di Kuwait Finance House Malaysia Berhad (KFHMB). Jurnal Teknologi, 55(1), 107-119.

Smolo, E., \& Kabir Hassan, M. (2011). The potentials of mushārakah mutanāqisah for Islamic housing finance. International Journal of Islamic and Middle Eastern Finance and Management, 4(3), 237-258.

Suhaimi, A. Y. (2010). Ijarah dari konteks Aplikasi, Perundangan dan Syariah. The paper is presented at the 4th Muzakarah Syariah Nusantara Muzakarah, Putrajaya International Convention Center.

The National Land Code, Section 4 (2).

Winsted, R. (1958). A history of classical Malay literature. Journal of the Malayan Branch of the Royal Asiatic Society, 31(3 (183), 3-259.

Yakcob, N. M. (1996). Teori, Amalan dan Prospek Sistem Kewangan Islam di Malaysia. Kuala Lumpur Yasin, N. M. (1996). Islamization/Malaynizaton: A Study of the Role of Islamic Law in the Economic Development of Malaysia: 1969-1993. Kuala Lumpur

ZAIN, M., \& NOOR, M. (2017). Maqasid Pengharaman Pembiayaan Peribadi Berlandaskan Bay' al'Inah di Malaysia. Islamiyyat: International Journal of Islamic Studies, 39(2). 